\title{
Impact of Specific Bowel Symptoms on Quality of Life in Patients with Midgut Neuroendocrine Tumours
}

\author{
Håkan Ohlsson ${ }^{1,2} \cdot$ Gideon Wahlberg $^{2,3} \cdot$ Marlene Malmström $^{3,4} \cdot$ Rita Gustafsson $^{2,3}$ • \\ Anna Sundlöv ${ }^{2,5}$ • Erik Nordenström ${ }^{2,6}$ - Martin Almquist ${ }^{2,6}$
}

\begin{abstract}
Introduction Patients with midgut neuroendocrine tumours (NETs) suffer from decreased health-related quality of life (HRQoL), in large part due to bowel symptoms. However, it is unknown which bowel symptoms affect HRQoL the most. An enhanced understanding of this is essential to better focus treatment on this aspect of the disease. This study aimed to determine which bowel symptoms affect HRQoL the most in patients with midgut NETs.

Methods Consenting patients with midgut NET completed the Memorial Sloan Kettering Bowel Function Instrument and the HRQoL questionnaire (EORTC QLQ-C30). The correlation between bowel symptoms and HRQoL was analysed using multiple linear regression, adjusting for age, Charlson Comorbidity Index score, presence of metastatic disease, chromogranin A, and BMI yielding B-coefficients with $95 \%$ confidence intervals.

Results Totally, 119 patients with midgut NET completed the questionnaires and were included in the study. Loose stool and bowel frequency $\geq 3$ /day were the most common bowel symptoms, reported by $47 \%$ and $56 \%$ of patients, respectively. However, sensitivity to certain types of food and beverages, a feeling of incomplete emptying of the bowel, and soiling were the symptoms most strongly correlated with decreased HRQoL, especially within domains concerning role and social function, with B-coefficients for the strongest correlated symptoms of 15.0 and 14.6, respectively.

Discussion While symptoms concerning stool consistency and frequency are common in patients with midgut NET, our study suggests that other, more socially stigmatising symptoms affect patients' HRQoL more. Our findings could help caregivers understand patients' perceptions of the disease and provide avenues for more directed therapies.
\end{abstract}

\section{Supplementary Information The online version contains} supplementary material available at https://doi.org/10.1007/s00268021-06146-9.

Håkan Ohlsson

hakan.ohlsson@med.lu.se

1 Department of Surgery, Ystad Hospital, VO Kirurgi, Lasarettet i Ystad, Kristianstadvägen 3, 27133 Ystad, Sweden

2 Institution of Clinical Sciences, Lund University, Lund, Sweden

3 Department of Surgery, Skåne University Hospital, Lund, Sweden
4 Department of Health Sciences, Lund University, Lund, Sweden

5 Department of Oncology, Skåne University Hospital, Lund, Sweden

6 Endocrine-Sarcoma Unit, Department of Surgery, Skåne University Hospital, Lund, Sweden 


\section{Introduction}

Following improved treatment during the last decades, survival of patients with midgut neuroendocrine tumours (NET) has improved markedly [1]. Consequently, with improved survival, an increased focus has been placed on the patients' self-experienced burden of the disease, i.e. health-related quality of life (HRQoL) [2, 3]. HRQoL is lower in patients with NET compared to the general population [4]. Causes of impaired HRQoL in patients with NET include symptoms such as fatigue, diarrhoea, and flushing $[5,6]$. Unfortunately, as the disease progresses, several of these symptoms often worsen, despite maximal symptomatic treatment [7] leading to chronically impaired HRQoL.

Bowel symptoms are frequent in patients with midgut NET and are often referred to non-specifically as "diarrhoea". Most previous studies on HRQoL in patients with NET have focused on the number of stool movements [6], but this aspect of bowel symptomatology might not in itself adequately portray the patients' bowel symptom burden. Symptoms such as urgency to pass stool, leakage, and sensitivity to certain food or beverages might also contribute to impaired HRQoL. In patients with colorectal cancer, such bowel symptoms have been explicitly evaluated $[8,9]$ and found to decrease HRQoL. To our knowledge, only one smaller $(n=35)$, interview-based, qualitative study with this aim has been conducted on patients with NET [10]. This study indicated that symptoms related to bowel movement frequency and urgency had the greatest impact on patients HRQoL, especially within social, occupational, physical, and emotional domains. To further improve patients' quality of life, a deeper understanding of which symptoms contribute the most to impaired HRQoL is imperative.

Our aim, therefore, was to study the relationship between specific bowel symptoms and HRQoL to understand which bowel symptoms explain the variance of HRQoL the most in patients with midgut NET. Another aim was to compare their HRQoL to that of the general population.

\section{Methods}

\section{Patients}

Patients alive on 1 September 2019 in the southern hospital region of Sweden and whose histopathological diagnosis of well-differentiated (G1-G2) NET with origin in the gastrointestinal tract had been established between 1 January 2000 and 31 December 2018 were eligible for inclusion.
The following exclusion criteria were used:

- Non-metastasised neuroendocrine tumours (NET) that only required endoscopic resection

- Appendiceal NET where appendectomy sufficed as the only treatment

- NET found incidentally during resection of another cancer

- Synchronous inoperable colorectal cancer

- Synchronous inflammatory bowel disease

Patients were identified by searching for gastrointestinal NET codes according to the Systematized Nomenclature of Medicine (SNOMED) system (see supplement for details) in the pathological database of the Skåne healthcare region. Eligible patients were invited by regular mail. Patients were sent questionnaires, as described below, and an informed consent form. If a patient did not reply within one month, one reminder letter was sent to the patient. Patients who replied that they did not wish to participate, and patients who did not reply within two months after one reminder, were considered non-responders. To minimise heterogeneity in the cohort and since bowel symptoms are most common from tumours with origin in the middle GItract, only patients with origin from small intestine, right colon, or appendix, i.e. the group previously denoted midgut NET, were included in the subsequent analysis. The complete cohort will be used for further studies on HRQoL in patients with GEP-NET.

\section{Questionnaires}

Since, to our knowledge, there is no bowel symptom instrument specifically designed and validated for patients with NET, we searched the literature for instruments used in patients with similar bowel symptoms. The Memorial Sloan Kettering Cancer Center Bowel Function Instrument (MSKCC-BFI) [11] consists of 18 items enquiring broadly and specifically into a range of bowel symptoms. This instrument has been validated for patients who have undergone rectal cancer surgery. The MSKCC-BFI uses plain English which, for this study, the authors translated into Swedish. Items in the MSKCC-BFI enquire how often symptoms occur: never, rarely, often, or always, except for the first item, which asks how many bowel movements a patient has per day. Answers to this item were transformed into quintiles, and answers from items $4,5,7,11$, and 12 were inverted, so that lower scores reflect more symptoms for all items, as per the reference manual [11].

Patients' HRQoL was evaluated with the cancer-specific, generic European Organisation for Research and Treatment of Cancer questionnaire EORTC QLQ-C30 [12]. This 30-item instrument is used to construct one Global Quality of Life scale (QL2) and five function scales: 
Physical Functioning (PF2), Role Functioning (RF2), Emotional Functioning (EF), Cognitive Functioning (CF), and Social Functioning (SF). These six scales were considered outcome variables and their values calculated and transformed into linear scales with 100 representing optimal function or high quality of life, according to the EORTC reference manual [13]. Answers from the diarrhoea symptom scale (DI) were reversed so that the value 100 indicates a severe symptom burden and 0 no symptoms.

\section{Medical records/medical information}

Information on previous disease, primary tumour site, presence of distant metastasis/residual tumour, Ki67 index at primary histopathological diagnosis, tumour grade, previous tumour surgeries, treatment with somatostatin analogue (SSA), treatment with anti-diarrhoeal agents or laxatives, levels of 24-h urine 5-hydroxyindoleacetic acid (U 5-HIAA), levels of serum chromogranin A, years since diagnosis, and previous or ongoing peptide-related radionuclide therapy (PRRT) or chemotherapy was obtained from patients' electronic medical records.

\section{Statistical analysis}

\section{Comparison with the general population}

To allow comparison with the general population, the difference between values of QL2, function scales, and DI in our cohort and corresponding values for the general Swedish population aged 60-79 years [14] was calculated, yielding delta values. A one-sided t-test was used to investigate whether the difference was significant compared to the reference values mentioned above. Delta values 5-10 are generally considered small, 10-20 moderate, and $>20$ large in a clinical context [15].

\section{Missing data}

Missing values from the MSKCC-BFI were imputed using multiple imputation [16] with predictive mean matching [17], k-nearest neighbour $(\mathrm{knn})=10$, and 20 imputations using a fixed random seed number. Missing values for $\mathrm{U}$ 5-HIAA and Chromogranin A (CgA) were recoded into within reference range, above reference range, or missing. The outcome variables HRQoL function and global scales were not imputed; patients without information on specific outcome variables were left out of the analysis.

\section{Regression analysis}

Multiple linear regression analysis using each function scale and the global QL2 as outcome variables was performed to investigate the relationship between each symptom item as reported in the MSKCC-BFI and HRQoL. Item 18, "Have you had to change daily activities due to bowel symptoms?" was omitted, since this item does not strictly enquire about symptoms, but about how symptoms affect daily activities.

The regression model was adjusted for patient and disease-related factors. Choice of inclusion of covariates was based on a combination of biological and statistical reasoning: Sex, age, Charlson Comorbidity Index score (Charlson CMI), U 5-HIAA, CgA, distant metastasis, any residual intra-abdominal tumour on radiology, SSA treatment, BMI, years since diagnosis, and type of tumour surgery were all included in the model based on a biological presumption that these variables are important for HRQoL. Of these, only variables with $p<0.1$ in any of the models were retained in the main analysis.

In the first linear regression model, each item of the MSKCC-BFI was investigated separately; in the second model, all items of the MSKCC-BFI were included simultaneously.

\section{Results}

Between 1 January 2000 and 31 December 2018, 806 unique patients were registered with GI-tract NET diagnosis codes. Of these, 561 patients were excluded following the predefined exclusion criteria. Between 2 September 2019 and 27 September 2019, the remaining 245 patients were invited by regular mail to participate in the study. Of these, three declined to participate, and 10 had to be excluded due to unknown address or emigration. A further 67 patients did not respond. The remaining 165 patients returned the completed instruments and signed the consent forms, resulting in a response rate of $67 \%$. In this study, to minimise heterogeneity, only the 119 patients with small intestine, right colon, or appendix primary site were included.

\section{Patient characteristics}

Mean (standard deviation, s.d.) age of the patients was 70.4 (10.7) years; $61 \%$ were men. Mean (s.d.) time since diagnosis was 6.4 (3.7) years. A total of 71 patients $(60 \%)$ had metastatic disease at the time of the study, and 59 of them were receiving SSA treatment. A further 11 patients without metastatic disease were also receiving SSA treatment, giving a total of 70 patients $(59 \%)$ receiving SSA 
Table 1 Cohort characteristics

\begin{tabular}{|c|c|c|c|c|c|c|c|}
\hline & Mean (s.d.) & $\begin{array}{l}\text { Reference values } \\
\text { general pop 60-79 } \\
\text { years }\end{array}$ & Delta & $\begin{array}{l}p \text { value } \\
\text { for } t \text {-test }\end{array}$ & Median (i.q.r.) & $\begin{array}{l}\mathrm{n}(\%) \text { with } \\
\text { score }<50\end{array}$ & $n$ \\
\hline Age & $70.4(10.7)$ & & & & $73(64-78)$ & & 119 \\
\hline Charlson Comorbidity Index & $3.9(2.5)$ & & & & $3(2-5)$ & & 119 \\
\hline Weight & $76.4(17.5)$ & & & & $75(65-86)$ & & 118 \\
\hline Height & $171.7(18.1)$ & & & & $173(166-179)$ & & 118 \\
\hline BMI & $25.4(5.3)$ & & & & $\begin{array}{l}24.8 \\
\quad(21.9-27.9)\end{array}$ & & 118 \\
\hline Years since diagnosis & $6.4(3.7)$ & & & & $5.6(3.5-8.8)$ & & 119 \\
\hline QL2 (0-100) & $72.9(20.9)$ & 76.7 & 3.8 & 0.027 & $75(58.3-83.3)$ & $14(11.8)$ & 118 \\
\hline PF2 (0-100) & $82.6(20.1)$ & 86.1 & 3.5 & 0.031 & $86.7(73.3-100)$ & $11(9.2)$ & 119 \\
\hline RF2 (0-100) & $81.5(28.4)$ & 87.8 & 6.3 & 0.009 & $100(66.7-100)$ & $17(14.3)$ & 119 \\
\hline $\mathrm{EF}(0-100)$ & $81.8(22.3)$ & 87.5 & 5.7 & 0.003 & $91.7(66.7-100)$ & $12(10.0)$ & 118 \\
\hline CF $(0-100)$ & $84.8(20.1)$ & 88.0 & 3.2 & 0.05 & $91.7(83.3-100)$ & $6(5.0)$ & 118 \\
\hline SF $(0-100)$ & $80.6(26.1)$ & 91.3 & 10.7 & $<0.001$ & $100(66.7-100)$ & $13(10.9)$ & 118 \\
\hline \multirow[t]{3}{*}{ DI $(0-100)$} & $35.9(35.4)$ & 5.4 & 30.5 & $<0.001$ & $33.3(0-66.7)$ & $38 *(31.9 *)$ & 118 \\
\hline & Yes & No & Missing & & & & \\
\hline & $n(\%)$ & $n(\%)$ & $n(\%)$ & & & & \\
\hline $\begin{array}{l}\text { Chromogranin } \mathrm{A} \geq 2 \mathrm{nmol} / \\
\mathrm{L}\end{array}$ & $63(52.9)$ & $51(43.9)$ & $5(4.2)$ & & & & \\
\hline Urine 5 -HIAA $\geq 30 \mu \mathrm{mol} / \mathrm{d}$ & $51(42.9)$ & $62(52.1)$ & $6(5.0)$ & & & & \\
\hline Male sex & $73(61.3)$ & $46(38.7)$ & - & & & & \\
\hline Metastatic disease & $71(59.7)$ & $48(40.3)$ & - & & & & \\
\hline \multirow[t]{6}{*}{ Grade } & Grade 1 & Grade 2 & Missing & & & & \\
\hline & $\begin{array}{l}(\mathrm{Ki} 67 \\
0-2 \%)\end{array}$ & (Ki67 3-20\%) & & & & & \\
\hline & $\mathrm{n}(\%)$ & n $(\%)$ & n $(\%)$ & & & & \\
\hline & $85(72.0)$ & $31(26.3)$ & $3(2.5)$ & & & & \\
\hline & Ongoing & Previous & None & & & & \\
\hline & $\mathrm{n}(\%)$ & $\mathrm{n}(\%)$ & $\mathrm{n}(\%)$ & & & & \\
\hline Chemotherapy & $0(0)$ & $7(5.9)$ & $\begin{array}{l}112 \\
\quad(94.1)\end{array}$ & & & & \\
\hline PRRT & $5(4.2)$ & $14(11.8)$ & $\begin{array}{l}100 \\
(84.0)\end{array}$ & & & & \\
\hline SSA treatment & $70(58.8)$ & & $49(41.2)$ & & & & \\
\hline Creon treatment & $17(14.3)$ & & $\begin{array}{l}102 \\
\quad(85.7)\end{array}$ & & & & \\
\hline Cholestyramine treatment & $5(4.2)$ & & $\begin{array}{l}114 \\
(95.8)\end{array}$ & & & & \\
\hline Antidiarrheal medication & $27(22.7)$ & & $92(77.3)$ & & & & \\
\hline Use of laxatives & $6(5.0)$ & & $\begin{array}{l}113 \\
(95.0)\end{array}$ & & & & \\
\hline Telotristat treatment & $3(2.5)$ & & $\begin{array}{l}116 \\
(97.5)\end{array}$ & & & & \\
\hline
\end{tabular}

${ }^{\dagger}$ Age-adjusted reference values from Derogar et al.

*For symptom scales, higher score indicates more severe symptoms

$Q L 2$ Global Quality of Life, $P F 2$ Physical Function, $R F 2$ Role Function, EF Emotional Function, CF Cognitive Function, $S F$ Social Function. 5-HIAA 5-Hydroxyindoleacetic acid 
Table 2 Previous tumour surgery

\begin{tabular}{|c|c|c|c|c|c|}
\hline Previous Tumour surgery: & yes $(\%)$ & $\begin{array}{l}\text { mean } \\
\text { DI-score }\end{array}$ & no & $\begin{array}{l}\text { mean } \\
\text { DI-score }\end{array}$ & $\begin{array}{l}\mathrm{p} \text {-value for } \\
\text { t-test }\end{array}$ \\
\hline Small bowel resection & $67(56.3)$ & 34.3 & $52(43.7)$ & 37.9 & 0.59 \\
\hline Rightsided hemicolectomy or ileocecal resection & $58(49.6)$ & 37.9 & $61(50.4)$ & 33.9 & 0.54 \\
\hline Both small bowel resection and rightsided resection & $10(8.4)$ & 36.7 & 109 (91.6) & 35.8 & 0.94 \\
\hline Other colorectal resection & $3(2.5)$ & 66.7 & $116(97.5)$ & 35.1 & 0.13 \\
\hline Liver resection & $4(3.4)$ & - & $115(96.6)$ & - & - \\
\hline Distal pancreatic resection & $2(1.7)$ & - & $117(98.3)$ & - & - \\
\hline No surgery & $3(2.5)$ & - & $116(97.5)$ & - & - \\
\hline
\end{tabular}

Categories not mutually exclusive, i.e. some patients have undergone several types of procedures

treatment. Of the 51 patients (43\%) with u-5HIAA levels above upper limit of normal (ULN), 16 patients had very high levels $(>10 \times \mathrm{ULN}, 300 \mu \mathrm{mol} / \mathrm{d})$, indicating severe endocrinopathy; 112 patients had small intestine or right colon origin; 7 patients had appendix origin. Some 67 patients had undergone small bowel resection; 58 patients had undergone a right-sided resection. In 2 patients with small intestinal NET metastatic to the pancreas, pancreatic resection was performed in addition to bowel surgery. Resection of bowel was not associated with higher scores of the EORTC-GI.NET21 symptom subscale diarrhea (DI). For more details about treatment and patient factors, see Tables 1 and 2.

\section{Health-related quality of life and bowel symptoms}

The mean values for QL2 and the five function scales were all significantly $(p<0.05)$ below the reference values of the general population aged 60-79 years in Sweden. However, only SF were sufficiently low compared to the general population to be considered clinically relevant. The mean value for the symptom scale "Diarrhoea" (DI) was 35.9 (s.d. 35.4), which is significantly higher than the 5.4 (delta 30.5 ) mean of the age-adjusted general population. See Table 1 for details.

Table 3 displays the results of the MSKCC-BFI. The mean number of bowel movements per day was 2.7 (s.d. 1.7, range: $1-9)$; 67 patients $(57 \%)$ had $>3$ bowel movements per day. The four most frequent symptoms (often/ always) reported were: loose stool, $n=55$ (47\%), not being able to wait $15 \mathrm{~min}$ when about to have a bowel movement, $n=40$ (34\%), presence of loose stool, i.e. diarrhoea, $n=37,(31 \%)$, and having another bowel movement within $15 \mathrm{~min}$ of the last one, $n=28(24 \%)$.

Adjusted multiple linear regression showed that age, Charlson CMI, presence of metastatic disease, chromogranin A above reference range, and BMI were independently associated with at least one of the outcome variables with significance level $p<0.1$. Consequently, these were included in the subsequent multiple regression models.

Table 4 displays the results from the repeated, separate, multiple regression models investigating the association between bowel symptoms and QL2/function scales. All significant associations were positive, indicating lower quality of life with more symptoms. Symptoms concerning soiling of undergarments, having to limit types of liquids or food, feeling of incomplete emptying of bowel had the most impact on both QL2 and the five function scales. For the subscales Role Function and Social Function, the Bcoefficients were generally higher than for the other subscales, e.g. 13.0, 95\% CI: 8.3-17.6 for RF2 vs item 14 (not getting to the toilet on time).

Table 5 displays the results of the multiple linear regression, including adjusting variables and all items from the MSKCC-BFI except item 18 (step 2 of the main analysis). Only the symptoms "feeling that bowel has not fully emptied after bowel movement" (item 4), "having to limit food to control bowel movements" (item 13) and "soiling of undergarments during the day" (item 15) were statistically significantly associated with HRQoL. For the subscales Global Quality of Life (QL2) and Physical Function (PF2), no symptom was statistically significant.

\section{Discussion}

In this study on 119 patients with midgut NET, HRQoL was significantly lower than in the general population. However, in line with previous studies $[4,6]$ the absolute difference was small. Furthermore, bowel symptoms were common; the most common was loose stool, $n=55$ (47\%), not being able to wait $15 \mathrm{~min}$ when about to have a bowel movement, $n=40$ (34\%), and having another bowel movement within $15 \mathrm{~min}$ of the last one, $n=28$ (24\%). All bowel symptoms affected HRQoL negatively, but the most common symptoms mentioned above did not have the most 
Table 3 Bowel symptom prevalence

\begin{tabular}{|c|c|c|c|c|c|c|}
\hline \multirow{3}{*}{$\begin{array}{l}\text { Item } \\
1\end{array}$} & & Reverted & & & & Total \\
\hline & \multirow{2}{*}{$\begin{array}{l}\text { Over the last } 4 \text { weeks, how many } \\
\text { bowel movements do you } \\
\text { generally have in } 24 \mathrm{~h} \text { ? }\end{array}$} & & \multicolumn{3}{|c|}{ mean 2.7 times/day (s.d. 1.7), range $1-9$} & \multirow[t]{2}{*}{115} \\
\hline & & & $\begin{array}{l}\text { Always/most of the time }(>1 / \\
\text { week) } \mathrm{n}(\%)\end{array}$ & $\begin{array}{l}\text { Sometimes (1/ } \\
\text { week) n (\%) }\end{array}$ & $\begin{array}{l}\text { Rarely/never }(<1 / \\
\text { week) n }(\%)\end{array}$ & \\
\hline 2 & $\begin{array}{l}\text { Do certain solid foods increase the } \\
\text { number of bowel movements in a } \\
\text { day? }\end{array}$ & & $19(16.0)$ & $40(33.6)$ & $60(50.4)$ & 119 \\
\hline 3 & $\begin{array}{l}\text { Do certain liquids that you drink } \\
\text { increase the number of bowel } \\
\text { movements in a day? }\end{array}$ & & $14(11.8)$ & $17(14.3)$ & $88(74.0)$ & 119 \\
\hline 4 & $\begin{array}{l}\text { Do you feel like you have totally } \\
\text { emptied your bowels after a bowel } \\
\text { movement? }\end{array}$ & yes & $79(67.0)$ & $24(20.3)$ & $15(12.7)$ & 118 \\
\hline 5 & Do you get to the toilet on time? & yes & $105(89.0)$ & $6(5.1)$ & $7(5.9)$ & 118 \\
\hline 6 & $\begin{array}{l}\text { Do you have another bowel } \\
\text { movement within } 15 \text { min of } \\
\text { your last bowel movement? }\end{array}$ & & $28(23.5)$ & $28(23.53)$ & $63(52.9)$ & 119 \\
\hline 7 & $\begin{array}{l}\text { Do you know the difference } \\
\text { between having to pass gas (air) } \\
\text { and needing to have a bowel } \\
\text { movement? }\end{array}$ & yes & $80(67.8)$ & $18(15.3)$ & $20(17.0)$ & 118 \\
\hline 8 & $\begin{array}{l}\text { Have you used medicines to } \\
\text { decrease the number of bowel } \\
\text { movements? }\end{array}$ & & $25(21.2)$ & $11(9.3)$ & $82(69.5)$ & 118 \\
\hline 9 & $\begin{array}{l}\text { Have you had diarrhea (no form, } \\
\text { watery stool)? }\end{array}$ & & $37(31.4)$ & $29(24.6)$ & $52(44.1)$ & 118 \\
\hline 10 & $\begin{array}{l}\text { Have you had loose stool (slight } \\
\text { form, but mushy)? }\end{array}$ & & 55 (46.6) & $38(32.2)$ & $25(21.2)$ & 118 \\
\hline 11 & $\begin{array}{l}\text { Have you been able to wait } 15 \\
\text { minutes to get to the toilet when } \\
\text { you feel like you are going to } \\
\text { have a bowel movement? }\end{array}$ & yes & 47 (39.8) & $31(26.3)$ & 40 (33.9) & 118 \\
\hline 12 & $\begin{array}{l}\text { Have you been able to control the } \\
\text { passage of gas (air)? }\end{array}$ & yes & $68(58.1)$ & $33(28.2)$ & $16(13.7)$ & 117 \\
\hline 13 & $\begin{array}{l}\text { Have you limited the types of solid } \\
\text { foods you eat to control your } \\
\text { bowel movements? }\end{array}$ & & $16(13.5)$ & $18(15.1)$ & 85 (71.4) & 119 \\
\hline 14 & $\begin{array}{l}\text { Have you limited the types of } \\
\text { liquids you drink to control you } \\
\text { bowel movements? }\end{array}$ & & $6(5.0)$ & $14(11.8)$ & 99 (83.2) & 119 \\
\hline 15 & $\begin{array}{l}\text { Have you had soilage (leakage of } \\
\text { stool) of your undergarments } \\
\text { during the day? }\end{array}$ & & $11(9.2)$ & 21 (17.6) & $87(73.1)$ & 119 \\
\hline 16 & $\begin{array}{l}\text { Have you used a tissue, napkin, } \\
\text { and/or pad in your } \\
\text { undergarments during the day in } \\
\text { case of stool leakage? }\end{array}$ & & $14(11.8)$ & $8(6.7)$ & 97 (81.5) & 119 \\
\hline
\end{tabular}


Table 3 continued

\begin{tabular}{lllll}
\hline Item & \multicolumn{2}{c}{ Reverted } & & $\begin{array}{l}\text { Total } \\
(n)\end{array}$ \\
\hline 17 & $\begin{array}{l}\text { Have you had soilage (leakage of } \\
\text { stool) of your undergarments } \\
\text { when you go to bed? }\end{array}$ & $2(1.7)$ & 119 \\
$18 \quad \begin{array}{l}\text { Have you had to alter your } \\
\text { activities because of your bowel } \\
\text { function? }\end{array}$ & $25(21.2)$ & $14(11.9)$ & $79(67.4)$ & 118 \\
\end{tabular}

negative impact on HRQoL. Instead, symptoms of soiling, feeling that the bowel had not fully emptied after a bowel movement, and having to limit what to eat or drink, had the strongest negative effect on HRQoL.

To our knowledge, this has not been reported previously. A global, internet-based study in 2017 indicated that bowel symptoms are the next most common symptom in patients with NET, preceded only by fatigue/muscle weakness, and that the symptoms have a large impact on patients' ability to lead their lives [18]. A smaller, qualitative study with 35 patients following a phase III trial of telotristat ethyl showed that an increased number of bowel movements and feelings of urgency associated with NET led to impaired emotional, social, physical, and occupational well-being [10]. The largest study so far to investigate the relationship between diarrhoea and HRQoL included 663 patients with NET [6] and showed a strong correlation between an increased number of bowel movements per day and worsened physical and social function. Our study complements these findings. The mechanisms for bowel symptoms are quite different in patients with midgut NET compared to patients having undergone surgery for colorectal cancer, suggesting that the findings from the latter group might not be applicable to the former. Nevertheless, the findings of our study correspond well to studies on bowel symptoms in patients with colorectal cancer [8, 9].

A potential explanation for the findings of this study is that while most patients with midgut NET experience frequent, loose stools, patients have learned to live with these symptoms. Conversely, symptoms concerning soiling and food intolerance can be expected to be associated with significant social stigma and thus might impair HRQoL more, especially within domains concerning social and role-functioning. Consequently, the results of the study indicate that to improve HRQoL in patients with midgut $\mathrm{NET}$, in addition to reducing the number of bowel movements, the more troublesome symptoms of soiling, food intolerance, and feeling of incomplete bowel emptying should also be addressed. Hence, the present study points to potential future interventional trials.

Strengths of the present study include the populationbased design, which reduces selection bias that can occur when inviting patients through patient organisations or other channels. The fact that different multiple regression models yielded similar results also strengthens the conclusions of the study.

One limitation of the study is that the MSKCC-BFI questionnaire has not been validated for patients with NET. To minimise the inferential risks from using a non-validated instrument, we chose not to base our regression models on the multi-item scales of the MSKCC-BFI. Instead, we included each question in the regression. This is in line with a previous study investigating bowel dysfunction after sigmoid resection due to colon cancer [8]. While there is a NET-specific instrument, the EORTCQLQ GI.NET21 [19], we chose not to use it for the present study, since it does not inquire about bowel symptoms with sufficient detail. Another limitation is that only $14 \%$ of the patients in the cohort received Creon. Since the study was conducted, the use of Creon has become more prevalent in patients with SSA. This discrepancy might indicate that some patients in the cohort had untreated pancreas insufficiency. While this might have a small effect on the prevalence of bowel symptoms, it is unlikely to affect the relationship between bowel symptoms and HRQoL.

To conclude, this study confirms the high prevalence of bowel symptomatology for patients with a midgut NET diagnosis. It adds new, previously unknown relevant information about which bowel symptoms are the most frequent and which symptoms impact HRQoL the most. For patients with midgut NET, the go-to question for caregivers so far has concerned the number of bowel movements per day. While this variable is objective and easy to measure, this study indicates that other bowel symptoms might be more troublesome. Consequently, if the goal is increased HRQoL, this study suggests that caregivers should focus on other, more socially stigmatising symptoms. 
Table 4 Multiple linear regression, symptoms analysed in separate models. Adjusted for age, Charlson Comorbidity Index, Chromogranin A level above reference range, metastatic disease, BMI

\begin{tabular}{|c|c|c|c|c|c|c|c|}
\hline Item & Question & $\begin{array}{l}\text { QL2 } \\
\text { B-coefficient } \\
(95 \% \mathrm{CI})\end{array}$ & $\begin{array}{l}\text { PF2 } \\
\text { B-coefficient } \\
(95 \% \mathrm{CI})\end{array}$ & $\begin{array}{l}\text { RF2 } \\
\text { B-coefficient } \\
(95 \% \mathrm{CI})\end{array}$ & $\begin{array}{l}\text { EF } \\
\text { B-coefficient } \\
(95 \% \mathrm{CI})\end{array}$ & $\begin{array}{l}\text { CF } \\
\text { B-coefficient } \\
(95 \% \mathrm{CI})\end{array}$ & $\begin{array}{l}\text { SF } \\
\text { ß-coefficient } \\
(95 \% \mathrm{CI})\end{array}$ \\
\hline 1 & $\begin{array}{l}\text { Over the last } 4 \text { weeks, how many } \\
\text { bowel movements do you } \\
\text { generally have in } 24 \mathrm{~h} \text { ? }\end{array}$ & $\begin{array}{l}4.18 \\
(1.71-6.66)\end{array}$ & $\begin{array}{l}3.28 \\
(1.00-5.55)\end{array}$ & $\begin{array}{l}4.39 \\
(0.97-7.82)\end{array}$ & $\begin{array}{l}1.31 \\
(1.50-4.12)\end{array}$ & $\begin{array}{l}1.61 \\
(0.90-4.14)\end{array}$ & $\begin{array}{l}3.75 \\
(0.54-6.96)\end{array}$ \\
\hline 2 & $\begin{array}{l}\text { Do certain solid foods increase the } \\
\text { number of bowel movements in a } \\
\text { day? }\end{array}$ & $\begin{array}{l}3.51 \\
(0.01-7.05)\end{array}$ & $\begin{array}{l}5.77 \\
(2.57-8.96)\end{array}$ & $\begin{array}{l}6.54 \\
(1.69-11.39)\end{array}$ & $\begin{array}{l}1.64 \\
(2.28-5.58)\end{array}$ & $\begin{array}{l}2.32 \\
(1.20-5.85)\end{array}$ & $\begin{array}{l}5.91 \\
(1.53-10.30)\end{array}$ \\
\hline 3 & $\begin{array}{l}\text { Do certain liquids that you drink } \\
\text { increase the number of bowel } \\
\text { movements in a day? }\end{array}$ & $\begin{array}{l}3.48 \\
(0.11-6.86)\end{array}$ & $\begin{array}{l}3.84 \\
(0.69-7.01)\end{array}$ & $\begin{array}{l}4.50 \\
(0.22-9.23)\end{array}$ & $\begin{array}{l}1.72 \\
(2.03-5.48)\end{array}$ & $\begin{array}{l}3.15 \\
(0.19-6.50)\end{array}$ & $\begin{array}{l}4.18 \\
(0.07-8.43)\end{array}$ \\
\hline 4 & $\begin{array}{l}\text { Do you feel like you have totally } \\
\text { emptied your bowels after a } \\
\text { bowel movement? }\end{array}$ & $\begin{array}{l}6.34 \\
(2.97-9.71)\end{array}$ & $\begin{array}{l}7.14 \\
(4.05-10.24)\end{array}$ & $\begin{array}{l}9.95 \\
(5.30-14.60)\end{array}$ & $\begin{array}{l}7.62 \\
(3.96-11.29)\end{array}$ & $\begin{array}{l}3.83 \\
(0.36-7.30)\end{array}$ & $\begin{array}{l}8.76 \\
(4.57-12.95)\end{array}$ \\
\hline 5 & Do you get to the toilet on time? & $\begin{array}{l}5.21 \\
(1.13-9.30)\end{array}$ & $\begin{array}{l}7.19 \\
(3.48-10.91)\end{array}$ & $\begin{array}{l}7.99 \\
(2.32-13.65)\end{array}$ & $\begin{array}{l}5.28 \\
(0.79-9.78)\end{array}$ & $\begin{array}{l}5.83 \\
(1.82-9.84)\end{array}$ & $\begin{array}{l}7.99 \\
(2.93-13.05)\end{array}$ \\
\hline 6 & $\begin{array}{l}\text { Do you have another bowel } \\
\text { movement within } 15 \text { min of } \\
\text { your last bowel movement? }\end{array}$ & $\begin{array}{l}4.02 \\
(0.93-7.11)\end{array}$ & $\begin{array}{l}5.31 \\
(2.50-8.12)\end{array}$ & $\begin{array}{l}4.83 \\
(0.50-9.16)\end{array}$ & $\begin{array}{l}4.90 \\
(1.53-8.26)\end{array}$ & $\begin{array}{l}4.01 \\
(0.95-7.06)\end{array}$ & $\begin{array}{l}6.35 \\
(2.53-10.17)\end{array}$ \\
\hline 7 & $\begin{array}{l}\text { Do you know the difference between } \\
\text { having to pass gas (air) and needing to } \\
\text { have a bowel movement? }\end{array}$ & $\begin{array}{l}2.72 \\
(0.18-5.62)\end{array}$ & $\begin{array}{l}1.94 \\
(0.81-4.70)\end{array}$ & $\begin{array}{l}3.44 \\
(0.62-7.51)\end{array}$ & $\begin{array}{l}2.19 \\
(1.02-5.40)\end{array}$ & $\begin{array}{l}1.98 \\
(0.91-4.87)\end{array}$ & $\begin{array}{l}3.76 \\
(0.11-7.41)\end{array}$ \\
\hline 8 & $\begin{array}{l}\text { Have you used medicines to } \\
\text { decrease the number of bowel } \\
\text { movements? }\end{array}$ & $\begin{array}{l}5.46 \\
(3.29-7.64)\end{array}$ & $\begin{array}{l}4.77 \\
(2.65-6.88)\end{array}$ & $\begin{array}{l}5.63 \\
(2.40-8.85)\end{array}$ & $\begin{array}{l}4.92 \\
(2.43-7.41)\end{array}$ & $\begin{array}{l}2.36 \\
(0.02-4.71)\end{array}$ & $\begin{array}{l}4.03 \\
(1.06-7.00)\end{array}$ \\
\hline 9 & $\begin{array}{l}\text { Have you had diarrhoea (no form, } \\
\text { watery stool)? }\end{array}$ & $\begin{array}{l}3.80 \\
(0.64-6.96)\end{array}$ & $\begin{array}{l}4.42 \\
(1.47-7.37)\end{array}$ & $\begin{array}{l}4.27 \\
(0.21-8.76)\end{array}$ & $\begin{array}{l}3.26 \\
(0.24-6.78)\end{array}$ & $\begin{array}{l}3.43 \\
(0.29-6.57)\end{array}$ & $\begin{array}{l}6.60 \\
(2.72-10.48)\end{array}$ \\
\hline 10 & $\begin{array}{l}\text { Have you had loose stool (slight } \\
\text { form, but mushy)? }\end{array}$ & $\begin{array}{l}1.75 \\
(1.61-5.12)\end{array}$ & $\begin{array}{l}0.68 \\
(2.49-3.87)\end{array}$ & $\begin{array}{l}0.82 \\
(3.89-5.54)\end{array}$ & $\begin{array}{l}1.04 \\
(4.75-2.65)\end{array}$ & $\begin{array}{l}1.30 \\
(4.63-2.02)\end{array}$ & $\begin{array}{l}2.15 \\
(2.07-6.38)\end{array}$ \\
\hline 11 & $\begin{array}{l}\text { Have you been able to wait } 15 \text { min to get to } \\
\text { the toilet when you feel like you are } \\
\text { going to have a bowel movement? }\end{array}$ & $\begin{array}{l}2.66 \\
(0.03-5.30)\end{array}$ & $\begin{array}{l}3.79 \\
(1.35-6.23)\end{array}$ & $\begin{array}{l}3.29 \\
(0.43-7.02)\end{array}$ & $\begin{array}{l}2.89 \\
(0.00-5.80)\end{array}$ & $\begin{array}{l}2.33 \\
(0.29-4.95)\end{array}$ & $\begin{array}{l}3.78 \\
(0.48-7.08)\end{array}$ \\
\hline 12 & $\begin{array}{l}\text { Have you been able to control the } \\
\text { passage of gas (air)? }\end{array}$ & $\begin{array}{l}5.49 \\
(2.29-8.69)\end{array}$ & $\begin{array}{l}4.88 \\
(1.84-7.93)\end{array}$ & $\begin{array}{l}5.61 \\
(1.01-10.21)\end{array}$ & $\begin{array}{l}4.40 \\
(0.79-8.01)\end{array}$ & $\begin{array}{l}3.68 \\
(0.42-6.94)\end{array}$ & $\begin{array}{l}7.57 \\
(3.58-11.57)\end{array}$ \\
\hline 13 & $\begin{array}{l}\text { Have you limited the types of solid } \\
\text { foods you eat to control your } \\
\text { bowel movements? }\end{array}$ & $\begin{array}{l}6.57 \\
(3.95-9.19)\end{array}$ & $\begin{array}{l}6.16 \\
(3.69-8.63)\end{array}$ & $\begin{array}{l}10.01 \\
(6.42-13.59)\end{array}$ & $\begin{array}{l}7.53 \\
(4.69-10.38)\end{array}$ & $\begin{array}{l}3.73 \\
(0.95-6.51)\end{array}$ & $\begin{array}{l}9.85 \\
(6.71-12.99)\end{array}$ \\
\hline 14 & $\begin{array}{l}\text { Have you limited the types of } \\
\text { liquids you drink to control you } \\
\text { bowel movements? }\end{array}$ & $\begin{array}{l}7.79 \\
(4.35-11.2)\end{array}$ & $\begin{array}{l}8.56 \\
(5.42-11.7)\end{array}$ & $\begin{array}{l}12.96 \\
(8.32-17.59)\end{array}$ & $\begin{array}{l}9.91 \\
(6.25-13.56)\end{array}$ & $\begin{array}{l}5.24 \\
(1.67-8.81)\end{array}$ & $\begin{array}{l}11.00 \\
(6.77-15.22)\end{array}$ \\
\hline 15 & $\begin{array}{l}\text { Have you had soilage (leakage of } \\
\text { stool) of your undergarments } \\
\text { during the day? }\end{array}$ & $\begin{array}{l}6.92 \\
(3.69-10.12)\end{array}$ & $\begin{array}{l}8.80 \\
(5.99-11.62)\end{array}$ & $\begin{array}{l}12.70 \\
(8.50-16.91)\end{array}$ & $\begin{array}{l}8.96 \\
(5.54-12.39)\end{array}$ & $\begin{array}{l}8.18 \\
(5.10-11.26)\end{array}$ & $\begin{array}{l}11.82 \\
(8.05-15.59)\end{array}$ \\
\hline 16 & $\begin{array}{l}\text { Have you used a tissue, napkin, } \\
\text { and/or pad in your undergarments during } \\
\text { the day in case of stool leakage? }\end{array}$ & $\begin{array}{l}5.47 \\
(2.64-8.31)\end{array}$ & $\begin{array}{l}7.28 \\
(4.78-9.77)\end{array}$ & $\begin{array}{l}8.50 \\
(4.60-12.40)\end{array}$ & $\begin{array}{l}6.21 \\
(3.12-9.31)\end{array}$ & $\begin{array}{l}4.42 \\
(1.56-7.29)\end{array}$ & $\begin{array}{l}7.14 \\
(3.58-10.68)\end{array}$ \\
\hline 17 & $\begin{array}{l}\text { Have you had soilage (leakage of stool) of } \\
\text { your undergarments } \\
\text { when you go to bed? }\end{array}$ & $\begin{array}{l}10.08 \\
(4.73-15.42)\end{array}$ & $\begin{array}{l}9.27 \\
(4.38-14.16)\end{array}$ & $\begin{array}{l}15.00 \\
(7.84-22.16)\end{array}$ & $\begin{array}{l}11.47 \\
(5.64-17.31)\end{array}$ & $\begin{array}{l}7.53 \\
(2.10-12.96)\end{array}$ & $\begin{array}{l}14.61 \\
(8.02-21.19)\end{array}$ \\
\hline
\end{tabular}


Table 4 continued

\begin{tabular}{|c|c|c|c|c|c|c|c|}
\hline Item & Question & $\begin{array}{l}\text { QL2 } \\
\text { ß-coefficient } \\
(95 \% \mathrm{CI})\end{array}$ & $\begin{array}{l}\text { PF2 } \\
\text { B-coefficient } \\
(95 \% \text { CI })\end{array}$ & $\begin{array}{l}\text { RF2 } \\
\text { ß-coefficient } \\
(95 \% \mathrm{CI})\end{array}$ & $\begin{array}{l}\mathrm{EF} \\
\text { ß-coefficient } \\
(95 \% \mathrm{CI})\end{array}$ & $\begin{array}{l}\mathrm{CF} \\
\text { B-coefficient } \\
(95 \% \mathrm{CI})\end{array}$ & $\begin{array}{l}\text { SF } \\
\text { B-coefficient } \\
(95 \% \text { CI) }\end{array}$ \\
\hline 18 & $\begin{array}{l}\text { Have you had to alter your } \\
\text { activities because of your bowelfunction? }\end{array}$ & $\begin{array}{l}8.65 \\
(6.32-10.98)\end{array}$ & $\begin{array}{l}8.31 \\
(6.14-10.47)\end{array}$ & $\begin{array}{l}12.70 \\
(9.55-15.85)\end{array}$ & $\begin{array}{l}7.46 \\
(4.69-10.24)\end{array}$ & $\begin{array}{l}5.77 \\
(3.19-8.36)\end{array}$ & $\begin{array}{l}10.44 \\
(7.46-13.41)\end{array}$ \\
\hline
\end{tabular}

$Q L 2$ Global Quality of Life, $P F 2$ Physical Function, $R F 2$ Role Function, EF Emotional Function, $C F$ Cognitive Function, $S F$ Social Function

Table 5 Multiple linear regression, symptoms analysed in same model. Adjusted for age, Charlson Comorbidity Index, Chromogranin A level above reference range, metastatic disease, BMI

\begin{tabular}{|c|c|c|c|c|c|c|c|}
\hline Item & Question & $\begin{array}{l}\text { QL2 } \\
\text { ß-coefficient } \\
(95 \% \mathrm{CI})\end{array}$ & $\begin{array}{l}\text { PF2 } \\
\text { ß-coefficient } \\
(95 \% \mathrm{CI})\end{array}$ & $\begin{array}{l}\text { RF2 } \\
\text { B-coefficient } \\
(95 \% \mathrm{CI})\end{array}$ & $\begin{array}{l}\text { EF } \\
\text { ß-coefficient } \\
(95 \% \mathrm{CI})\end{array}$ & $\begin{array}{l}\mathrm{CF} \\
\text { ß-coefficient } \\
(95 \% \mathrm{CI})\end{array}$ & $\begin{array}{l}\text { SF } \\
\text { B-coefficient } \\
(95 \% \mathrm{CI})\end{array}$ \\
\hline 1 & $\begin{array}{l}\text { Over the last } 4 \text { weeks, how many } \\
\text { bowel movements do you } \\
\text { generally have in } 24 \mathrm{~h} \text { ? }\end{array}$ & ( $1.07-5.63)$ & ( 2.73-2.76) & ( $3.21-5.17)$ & $(5.96-1.30)$ & ( $3.81-3.09)$ & $(5.67-2.18)$ \\
\hline 2 & $\begin{array}{l}\text { Do certain solid foods increase the } \\
\text { number of bowel movements in a } \\
\text { day? }\end{array}$ & $\begin{array}{l}1.14 \\
(5.47-3.18)\end{array}$ & $\begin{array}{l}3.18 \\
(0.51-6.88)\end{array}$ & $\begin{array}{l}1.45 \\
(4.16-7.07)\end{array}$ & $\begin{array}{l}2.25 \\
(6.83-2.31)\end{array}$ & $\begin{array}{l}0.30 \\
(4.84-4.23)\end{array}$ & $\begin{array}{l}0.65 \\
(4.34-5.65)\end{array}$ \\
\hline 3 & $\begin{array}{l}\text { Do certain liquids that you drink } \\
\text { increase the number of bowel } \\
\text { movements in a day? }\end{array}$ & $\begin{array}{l}0.62 \\
(3.60-4.84)\end{array}$ & $\begin{array}{l}-0.95 \\
(4.63-2.73)\end{array}$ & $\begin{array}{l}0.99 \\
(6.59-4.61)\end{array}$ & $\begin{array}{l}0.35 \\
(4.81-4.11)\end{array}$ & $\begin{array}{l}1.57 \\
(2.85-6.00)\end{array}$ & $\begin{array}{l}1.25 \\
(6.13-3.62)\end{array}$ \\
\hline 4 & $\begin{array}{l}\text { Do you feel like you have totally } \\
\text { emptied your bowels after a } \\
\text { bowel movement? }\end{array}$ & $\begin{array}{l}2.49 \\
(1.70-6.69)\end{array}$ & $\begin{array}{l}2.53 \\
(1.12-6.18)\end{array}$ & $\begin{array}{l}5.64 * \\
(0.11-11.17)\end{array}$ & $\begin{array}{l}3.85 * \\
(0.59-8.31)\end{array}$ & $\begin{array}{l}0.63 \\
(3.76-5.04)\end{array}$ & $\begin{array}{l}3.49 \\
(1.36-8.35)\end{array}$ \\
\hline 5 & Do you get to the toilet on time? & $\begin{array}{l}0.92 \\
(4.80-6.65)\end{array}$ & $\begin{array}{l}4.28 \\
(0.73-9.29)\end{array}$ & $\begin{array}{l}3.13 \\
(4.48-10.76)\end{array}$ & $\begin{array}{l}0.36 \\
(6.44-5.71)\end{array}$ & $\begin{array}{l}1.29 \\
(4.70-7.30)\end{array}$ & $\begin{array}{l}0.92 \\
(5.70-7.55)\end{array}$ \\
\hline 6 & $\begin{array}{l}\text { Do you have another bowel } \\
\text { movement within } 15 \text { min of } \\
\text { your last bowel movement? }\end{array}$ & $\begin{array}{l}2.14 \\
(6.21-1.91)\end{array}$ & $\begin{array}{l}0.31 \\
(3.12-3.76)\end{array}$ & $\begin{array}{l}3.31 \\
(8.55-1.92)\end{array}$ & $\begin{array}{l}0.03 \\
(4.24-4.30)\end{array}$ & $\begin{array}{l}0.54 \\
(3.68-4.77)\end{array}$ & $\begin{array}{l}0.50 \\
(5.17-4.17)\end{array}$ \\
\hline 7 & $\begin{array}{l}\text { Do you know the difference between } \\
\text { having to pass gas (air) and needing } \\
\text { to have a bowel movement? }\end{array}$ & $\begin{array}{l}0.72 \\
(4.19-2.73)\end{array}$ & $\begin{array}{l}1.92 \\
(4.95-1.11)\end{array}$ & $\begin{array}{l}0.18 \\
(4.41-4.79)\end{array}$ & $\begin{array}{l}0.22 \\
(3.89-3.43)\end{array}$ & $\begin{array}{l}0.97 \\
(4.60-2.66)\end{array}$ & $\begin{array}{l}0.06 \\
(4.07-3.94)\end{array}$ \\
\hline 8 & $\begin{array}{l}\text { Have you used medicines to } \\
\text { decrease the number of bowel } \\
\text { movements? }\end{array}$ & $\begin{array}{l}2.88 \\
(0.27-6.05)\end{array}$ & $\begin{array}{l}0.61 \\
(2.19-3.42)\end{array}$ & $\begin{array}{l}-0.19 \\
(4.42-4.03)\end{array}$ & $\begin{array}{l}0.53 \\
(2.82-3.89)\end{array}$ & $\begin{array}{l}0.93 \\
(4.25-2.37)\end{array}$ & $\begin{array}{l}3.60 \\
(7.27-0.06)\end{array}$ \\
\hline 9 & $\begin{array}{l}\text { Have you had diarrhoea (no form, } \\
\text { watery stool)? }\end{array}$ & $\begin{array}{l}3.73 \\
(7.97-0.50)\end{array}$ & $\begin{array}{l}0.24 \\
(3.94-3.46)\end{array}$ & $\begin{array}{l}3.50 \\
(9.10-2.09)\end{array}$ & $\begin{array}{l}0.42 \\
(4.89-4.05)\end{array}$ & $\begin{array}{l}2.53 \\
(1.88-6.95)\end{array}$ & $\begin{array}{l}1.94 \\
(2.93-6.82)\end{array}$ \\
\hline 10 & $\begin{array}{l}\text { Have you had loose stool (slight } \\
\text { form, but mushy)? }\end{array}$ & $\begin{array}{l}0.98 \\
(2.72-4.69)\end{array}$ & $\begin{array}{l}1.71 \\
(4.92-1.49)\end{array}$ & $\begin{array}{l}0.94 \\
(5.82-3.93)\end{array}$ & $\begin{array}{l}1.71 \\
(5.62-2.18)\end{array}$ & $\begin{array}{l}3.93 * \\
(7.80-0.07)\end{array}$ & $\begin{array}{l}0.01 \\
(4.26-4.22)\end{array}$ \\
\hline 11 & $\begin{array}{l}\text { Have you been able to wait } 15 \text { min to } \\
\text { get to the toilet when you feel like } \\
\text { you are going to have a bowel } \\
\text { movement? }\end{array}$ & $\begin{array}{l}0.19 \\
(3.05-2.65)\end{array}$ & $\begin{array}{l}0.24 \\
(2.28-2.77)\end{array}$ & $\begin{array}{l}0.50 \\
(4.33-3.32)\end{array}$ & $\begin{array}{l}0.61 \\
(2.40-3.63)\end{array}$ & $\begin{array}{l}0.58 \\
(2.41-3.58)\end{array}$ & $\begin{array}{l}0.12 \\
(3.17-3.42)\end{array}$ \\
\hline 12 & $\begin{array}{l}\text { Have you been able to control the } \\
\text { passage of gas (air)? }\end{array}$ & $\begin{array}{l}2.86 \\
(1.18-6.91)\end{array}$ & $\begin{array}{l}0.69 \\
(2.84-4.23)\end{array}$ & $\begin{array}{l}1.43 \\
(3.92-6.79)\end{array}$ & $\begin{array}{l}0.41 \\
(3.85-4.68)\end{array}$ & $\begin{array}{l}0.29 \\
(4.52-3.93)\end{array}$ & $\begin{array}{l}3.96 \\
(0.68-8.60)\end{array}$ \\
\hline 13 & $\begin{array}{l}\text { Have you limited the types of solid } \\
\text { foods you eat to control your } \\
\text { bowel movements? }\end{array}$ & $\begin{array}{l}3.71 \\
(0.04-7.46)\end{array}$ & $\begin{array}{l}0.92 \\
(2.36-4.20)\end{array}$ & $\begin{array}{l}4.34 \\
(0.64-9.32)\end{array}$ & $\begin{array}{l}4.68^{*} \\
(0.71-8.65)\end{array}$ & $\begin{array}{l}1.03 \\
(2.90-4.97)\end{array}$ & $\begin{array}{l}6.47 * \\
(2.12-10.81)\end{array}$ \\
\hline
\end{tabular}


Table 5 continued

\begin{tabular}{|c|c|c|c|c|c|c|c|}
\hline Item & Question & $\begin{array}{l}\text { QL2 } \\
\text { B-coefficient } \\
(95 \% \mathrm{CI})\end{array}$ & $\begin{array}{l}\mathrm{PF} 2 \\
\text { ß-coefficient } \\
(95 \% \mathrm{CI})\end{array}$ & $\begin{array}{l}\text { RF2 } \\
\text { ß-coefficient } \\
(95 \% \mathrm{CI})\end{array}$ & $\begin{array}{l}\mathrm{EF} \\
\text { B-coefficient } \\
(95 \% \mathrm{CI})\end{array}$ & $\begin{array}{l}\text { CF } \\
\text { B-coefficient } \\
(95 \% \mathrm{CI})\end{array}$ & $\begin{array}{l}\text { SF } \\
\text { B-coefficient } \\
(95 \% \mathrm{CI})\end{array}$ \\
\hline 14 & $\begin{array}{l}\text { Have you limited the types of } \\
\text { liquids you drink to control you } \\
\text { bowel movements? }\end{array}$ & $\begin{array}{l}0.45 \\
(4.81-5.71)\end{array}$ & $\begin{array}{l}2.68 \\
(1.91-7.28)\end{array}$ & $\begin{array}{l}5.37 \\
(1.61-12.35)\end{array}$ & $\begin{array}{l}3.05 \\
(2.48-8.60)\end{array}$ & $\begin{array}{l}0.74 \\
(4.76-6.26)\end{array}$ & $\begin{array}{l}3.15 \\
(2.92-9.22)\end{array}$ \\
\hline 15 & $\begin{array}{l}\text { Have you had soilage (leakage of } \\
\text { stool) of your undergarments } \\
\text { during the day? }\end{array}$ & $\begin{array}{l}2.40 \\
(2.25-7.05)\end{array}$ & $\begin{array}{l}3.19 \\
(0.80-7.19)\end{array}$ & $\begin{array}{l}6.56^{*} \\
(0.49-12.64)\end{array}$ & $\begin{array}{l}4.10 \\
(0.80-9.02)\end{array}$ & $\begin{array}{l}7.19 * \\
(2.31-12.08)\end{array}$ & $\begin{array}{l}5.06 \\
(0.32-10.45)\end{array}$ \\
\hline 16 & $\begin{array}{l}\text { Have you used a tissue, napkin, } \\
\text { and/or pad in your undergarments } \\
\text { during the day in case of stool } \\
\text { leakage? }\end{array}$ & $\begin{array}{l}0.62 \\
(4.65-3.41)\end{array}$ & $\begin{array}{l}1.61 \\
(1.88-5.12)\end{array}$ & $\begin{array}{l}0.45 \\
(5.78-4.87)\end{array}$ & $\begin{array}{l}0.09 \\
(4.14-4.33)\end{array}$ & $\begin{array}{l}0.29 \\
(4.50-3.91)\end{array}$ & $\begin{array}{l}0.06 \\
(4.71-4.58)\end{array}$ \\
\hline 17 & $\begin{array}{l}\text { Have you had soilage (leakage of } \\
\text { stool) of your undergarments } \\
\text { when you go to bed? }\end{array}$ & $\begin{array}{l}2.73 \\
(4.02-9.49)\end{array}$ & $\begin{array}{l}0.19 \\
(5.66-6.06)\end{array}$ & $\begin{array}{l}2.85 \\
(6.04-11.75)\end{array}$ & $\begin{array}{l}3.70 \\
(3.46-10.87)\end{array}$ & $\begin{array}{l}-1.39 \\
(8.49-5.70)\end{array}$ & $\begin{array}{l}4.07 \\
(3.75-11.90)\end{array}$ \\
\hline 18 & $\begin{array}{l}\text { Have you had to alter your } \\
\text { activities because of your bowel } \\
\text { function? }\end{array}$ & $\begin{array}{l}- \\
-\end{array}$ & - & - & - & - & - \\
\hline
\end{tabular}

$=p<0.05$. $Q L 2$ Global Quality of Life, PF2 Physical Function, RF2 Role Function, EF Emotional Function, $C F$ Cognitive Function, $S F$ Social Function

Funding Open access funding provided by Lund University. This study was supported by a non-restricted research grant from IPSEN and Sparres Foundation. The funders had no role in the design, conduct, or reporting of this study.

\section{Declarations}

Conflict of interest The senior author has received research grants from IPSEN, and consultant fees from Medtronic, outside this study. AS has received speaker and consultancy fees from IPSEN, Novartis, Sam Nordic and Spago Nanomedical, none of which are related to this study. The other authors declare no conflicts of interest.

Ethical approval The study was approved by the Swedish Ethical Review Authority (dnr 2019-02378).

Informed consent All participating patients gave written informed consent.

Open Access This article is licensed under a Creative Commons Attribution 4.0 International License, which permits use, sharing, adaptation, distribution and reproduction in any medium or format, as long as you give appropriate credit to the original author(s) and the source, provide a link to the Creative Commons licence, and indicate if changes were made. The images or other third party material in this article are included in the article's Creative Commons licence, unless indicated otherwise in a credit line to the material. If material is not included in the article's Creative Commons licence and your intended use is not permitted by statutory regulation or exceeds the permitted use, you will need to obtain permission directly from the copyright holder. To view a copy of this licence, visit http://creativecommons. org/licenses/by/4.0/.

\section{References}

1. Dasari A, Shen C, Halperin D et al (2017) Trends in the incidence, prevalence, and survival outcomes in patients with neuroendocrine tumors in the United States. JAMA Oncol. https:// doi.org/10.1001/jamaoncol.2017.0589

2. Topping M, Gray D, Friend E et al (2017) A systematic review of symptoms and quality of life issues in pancreatic neuroendocrine tumours. Neuroendocrinology 105:320-330

3. Jiménez-Fonseca P, Carmona-Bayonas A, Martín-Pérez E et al (2015) Health-related quality of life in well-differentiated metastatic gastroenteropancreatic neuroendocrine tumors. Cancer Metastasis Rev 34:381-400. https://doi.org/10.1007/s10555-0159573-1

4. Fröjd C, Larsson G, Lampic C, von Essen L (2007) Health related quality of life and psychosocial function among patients with carcinoid tumours. A longitudinal, prospective, and comparative study. Health Qual Life Outcomes 5:1-9. https://doi.org/10.1186/ 1477-7525-5-18

5. Ruszniewski P, Valle JW, Lombard-Bohas C et al (2016) Patientreported outcomes with lanreotide Autogel/Depot for carcinoid syndrome: an international observational study. Dig Liver Dis 48:552-558. https://doi.org/10.1016/j.dld.2015.12.013

6. Beaumont JL, Cella D, Phan AT et al (2012) Comparison of health-related quality of life in patients with neuroendocrine tumors with quality of life in the general US population. Pancreas 41:461-466. https://doi.org/10.1097/MPA.0b013e3182328045

7. Riechelmann RP, Pereira AA, Rego JFM, Costa FP (2017) Refractory carcinoid syndrome: a review of treatment options. Ther Adv Med Oncol 9:127-137 
8. Elfeki H, Larsen HM, Emmertsen KJ et al (2019) Bowel dysfunction after sigmoid resection for cancer and its impact on quality of life. Br J Surg 106:142-151. https://doi.org/10.1002/ bjs. 10979

9. Emmertsen KJ, Laurberg S (2012) Low anterior resection syndrome score. Ann Surg 255:922-928. https://doi.org/10.1097/ SLA.0b013e31824f1c21

10. Anthony L, Ervin C, Lapuerta P et al (2017) Understanding the patient experience with carcinoid syndrome: exit interviews from a randomized, placebo-controlled study of telotristat ethyl. Clin Ther 39:2158-2168. https://doi.org/10.1016/j.clinthera.2017.09. 013

11. Temple LK, Bacik J, Savatta SG et al (2005) The development of a validated instrument to evaluate bowel function after sphincterpreserving surgery for rectal cancer. Dis Colon Rectum 48:1353-1365. https://doi.org/10.1007/s10350-004-0942-z

12. Aaronson NK, Ahmedzai S, Bergman B et al (1993) The European organization for research and treatment of cancer QLQ-C30: a quality-of-life instrument for use in international clinical trials in oncology. JNCI J Natl Cancer Inst 85:365-376. https://doi.org/ 10.1093/jnci/85.5.365

13. Fayers PM, Aaronson NK, Bjordal K, Groenvold M, Curran D, Bottomley A, on behalf of the EORTC Quality of Life Group. The EORTC QLQ-C30 Scoring Manual (3rd Edition). Published by: European Organisation for Research and Treatment of Cancer, Brussels 2001.
14. Derogar M, van der Schaaf M, Lagergren P (2012) Reference values for the EORTC QLQ-C30 quality of life questionnaire in a random sample of the Swedish population. Acta Oncol (Madr) 51:10-16. https://doi.org/10.3109/0284186X.2011.614636

15. Osoba D, Rodrigues G, Myles J et al (1998) Interpreting the significance of changes in health-related quality-of- life scores. J Clin Oncol 16:139-144. https://doi.org/10.1200/JCO.1998.16.1. 139

16. Sterne JAC, White IR, Carlin JB et al (2009) Multiple imputation for missing data in epidemiological and clinical research: potential and pitfalls. BMJ 339:157-160

17. Rubin DB (1986) Statistical matching using file concatenation with adjusted weights and multiple imputations. J Bus Econ Stat 4:87. https://doi.org/10.2307/1391390

18. Singh S, Granberg D, Wolin E et al (2017) Patient-reported burden of a neuroendocrine tumor (NET) diagnosis: results from the first global survey of patients with NETs. J Glob Oncol 3:43-53. https://doi.org/10.1200/JGO.2015.002980

19. Yadegarfar G, Friend L, Jones L et al (2013) Validation of the EORTC QLQ-GINET21 questionnaire for assessing quality of life of patients with gastrointestinal neuroendocrine tumours. Br J Cancer. https://doi.org/10.1038/bjc.2012.560

Publisher's Note Springer Nature remains neutral with regard to jurisdictional claims in published maps and institutional affiliations. 